\title{
Inheritance of Rootstock Effects and Their Association with Salt Tolerance Candidate Genes in a Progeny Derived from 'Volkamer' Lemon
}

\author{
Verónica Raga and Guillermo P. Bernet \\ Centro Protección Vegetal y Biotecnología, Instituto Valenciano de Investigaciones Agrarias, Apdo \\ Oficial, 46113 Moncada, Valencia, Spain \\ Emilio A. Carbonell \\ Unidad de Biometría, Instituto Valenciano de Investigaciones Agrarias, Apdo. Oficial, 46113 \\ Moncada, Valencia, Spain \\ Maria J. Asins ${ }^{1}$ \\ Centro Protección Vegetal y Biotecnología, Instituto Valenciano de Investigaciones Agrarias, Apdo \\ Oficial, 46113 Moncada, Valencia, Spain
}

\begin{abstract}
Additional Index words. Citrus, heritability, Poncirus, rootstock breeding, salt tolerance
Abstract. A seedling population from hybrids between 'Volkamer' lemon (Citrus volkameriana) and 'Rubidoux' trifoliate orange (Poncirus trifoliata) was grafted with 'Hashimoto' Satsuma mandarin (Citrus unshiu) to study the inheritance of rootstock effects on salt tolerance in terms of fruit yield. Trees were maintained in a screenhouse, and a salt treatment $(25 \mathrm{~mm} \mathrm{NaCl})$ was applied to 32 genotypes from June to September every year for 5 years. Rootstocks were genotyped for five salt tolerance candidate genes. Significant effects of rootstock genotype (G) and treatment (E) were found for most traits. Salinity decreased yield and juice volume but improved soluble solids concentration (TSS) and rind thickness. Year effects were highly significant in most cases. $\mathbf{G} \times \mathbf{E}$ interactions were found for fruit weight, total fruit weight, juice volume (JV), leaf water content (LWC), and leaf $\left[\mathrm{Na}^{+}\right]$. Therefore, rootstocks that induce early fruit maturation under salinity (by increasing TSS and maintaining JV) can be selected to expand the harvesting calendar of mandarin cultivars. Salt tolerance candidate genes SOS1 and NHX1 were associated with fruit yield traits under normal conditions (1.4 $\left.\mathrm{dS} \cdot \mathrm{m}^{-1}\right)$, and SOS1 and CCC were associated with LWC under salinity conditions ( $\left.4 \mathrm{dS} \cdot \mathrm{m}^{-1}\right)$. Only $5 \%$ progeny induced higher accumulated yield than 'Volkamer' lemon under salinity. Given the low heritability of rootstock effects on fruit yield under salinity conditions ( 0.18 at most), marker-assisted selection might be useful.
\end{abstract}

More than 800 million hectares of land throughout the world are affected by salinity (Food and Agriculture Organization of the United Nations, 2008), which can decrease yield and lead to increased poverty and reliance on imports (Witcombe et al., 2008). Citrus species are among the most salt-sensitive of horticultural crops, although differences in tolerance exist among species in these genera (Maas, 1993). Tree growth and fruit yield of citrus species are impaired at a soil salinity of $\approx 2 \mathrm{dS} \cdot \mathrm{m}^{-1}$ soil saturation without the concomitant expression of leaf symptoms (Bingham et al., 1974; Cerdá et al., 1990). Several lines of evidence indicate that citrus species are predominantly chloridesensitive (Bañuls et al., 1997; Cooper, 1961; Ruiz et al., 1999; Walker et al., 1982). Cooper et al. (1956) classified citrus rootstocks into three groups: 1) good salt tolerance ('Cleopatra' mandarin Citrus reshni); 2) medium salt tolerance ['Volkamer' lemon and sour orange (Citrus aurantium)]; and 3) poor salt tolerance [trifoliate orange and 'Troyer' or 'Carrizo' citrange (Citrus sinensis $\times$ Poncirus trifoliata) $]$. This classification

Received for publication 25 Feb. 2014. Accepted for publication 13 May 2014. This work has been partially supported by grants AGL2002-02395, FP6-2003INCO-MPC-2, RTA2006-0009-00-00, AGL2008-00197/AGR, RTA2011-00132C02, Fondo Social Europeo (G.P.B.), and IVIA (V.R.).

We thank Dr. Colmenero-Flores for providing the citrus CCC sequence and Mr. J. Puchades for the technical assistance.

${ }^{1}$ Corresponding author. E-mail: mjasins@ivia.es. agrees with the order of these genotypes according to their ability to restrict $\mathrm{Cl}^{-}$transport to the scion on grafted trees under field conditions (irrigation with saline) and in an experiment involving the culture of Satsuma mandarin (Citrus unshiu) rootstock combinations, which evaluated salt tolerance according to fruit and leaf characteristics (García et al., 2002). Chloride concentrations in the leaves of seedlings under salinity conditions have been used by most rootstock breeders to select salt-tolerant genotypes (Sykes, 1985). However, there are many examples of contradictory results related to the ability to exclude $\mathrm{Cl}^{-}$(Grieve and Walker, 1983); in most cases, it is not possible to determine whether experimental or genetic differences are responsible for these results. Thus, Sykes (2011) showed the presence of within-species diversity for chloride and sodium excluding capacities recommending progeny testing to investigate their inheritance for future rootstock breeding. Quantitative trait loci (QTL) analysis of these traits has been carried out in citrus seedlings (Tozlu et al., 1999).

Salt tolerance is a quantitative trait in plants. The identification of QTL that control salinity tolerance is of great importance for breeding salt-tolerant crops (Cuartero et al., 2006; Flowers, 2004; Koyama et al., 2001). However, QTL analysis of rootstock effects takes a long time as a result of the long juvenility period of citrus species and is very expensive because of the required time and huge cultivation costs for maintaining large segregating progenies. Besides, rootstock 
may affect numerous citrus attributes (Castle, 2010) making interpretation of data analysis very complicated. An alternative strategy is the analysis of candidate genes functionally involved in the salt tolerance response. These genes could serve as useful markers for early selection of rootstocks that confer salt tolerance to the grafted citrus cultivar. The regulation of ion homeostasis is one of the main strategies used by glycophytes for salinity-stress adaptation (Munns and Tester, 2008). It involves a network of transport processes that regulate the uptake, extrusion through the plasma membrane, compartmentalization of salts into cell vacuoles, and recirculation of ions through plant organs. This facilitates plant osmotic adjustment and maintenance of high $\mathrm{K}^{+} / \mathrm{Na}^{+}$ratios in the cytosol (Apse and Blumwald, 2007; Pardo and Rubio, 2011). Genes coding for cation transporters such as HKT (high-affinity $\mathrm{K}^{+}$transporter), SOS1 (salt overly sensitive), and NHX family $\left(\mathrm{Na}^{+} / \mathrm{H}^{+}\right.$exchangers) are considered candidate genes for salt tolerance because they regulate the internal concentrations of $\mathrm{Na}^{+}$in various tissues and indirectly regulate $\mathrm{K}^{+}$homeostasis (Munns and Tester, 2008; Yamaguchi et al., 2013). Porat et al. (2002) isolated NHX1 from citrus and found that it was markedly induced by salt stress in a salt-tolerant cell line form 'Shamouti' sweet orange (C. sinensis). Brumós et al. (2009) found that a cation-chloride cotransporter (AtCCC ortholog) was induced in 'Carrizo' citrange but not in 'Cleopatra' mandarin seedlings under salt treatment.

Following Shannon and Grieve (1999), salt tolerance values should take into consideration the portion of the plant to be marketed. Salinity effect on fruit yield has been reported almost exclusively by studies that used a single-scion/single-rootstock combination (reviewed by Grieve et al., 2007; Prior et al., 2007; Storey and Walker, 1999) or one cultivar grafted onto two genetically unrelated rootstocks (García-Sánchez et al., 2003, 2006; Navarro et al., 2010; Syvertsen et al., 2010). These studies used 'Cleopatra' mandarin and 'Carrizo' or 'Troyer' citrange. Therefore, the salinity response has been extensively studied in these rootstocks; however, the inheritance of the rootstock-mediated salt tolerance has been hardly approached in citrus. We report an inheritance study of salt tolerance in terms of mandarin fruit yield conferred by a segregating population of rootstocks derived from a medium salt-tolerant $C$. volkameriana and a salt-sensitive $P$. trifoliata cultivar. As possible tools for selection in future rootstock breeding programs, trait correlations and the association of candidate genes (primarily those involved in $\mathrm{Na}^{+}$and $\mathrm{Cl}^{-}$homeostasis) with traits involved in salt tolerance were also investigated.

\section{Materials and Methods}

Plant materials and growth conditions. A seedling population was developed by open pollination from an intergenic hybrid between 'Volkamer' lemon [V (female parent)] and 'Rubidoux' trifoliate orange [P (male parent)] obtained by J.B. Forner [Instituto Valenciano de Investigaciones Agrarias (IVIA), Valencia, Spain]. Twenty-five random seedlings derived from each individual $\mathrm{V} \times \mathrm{P}$ fruit-yielding tree were genotyped for five isozymatic loci (García et al., 1999) to infer their genetic origin (apomictic or sexual; sexual by crosspollination or self-pollination). Seedlings derived from crosspollination were discarded. The seedling population, and 10 seedlings each from two control genotypes ('Volkamer' lemon and 'Flying Dragon' trifoliate orange), were grafted with the 'Hashimoto' Satsuma mandarin in 1996.
Eighteen genotypes (13 derived from apomictic $\mathrm{V} \times \mathrm{P}$ hybrids) were grown as control treatment (no $\mathrm{NaCl}$ added), and 32 genotypes (20 derived from apomictic $\mathrm{V} \times \mathrm{P}$ hybrids) were grown under salinity conditions. Thirteen genotypes derived from $\mathrm{V} \times \mathrm{P}$ apomictic hybrids (i.e., those yielding seedlings that are genetically identical to the mother hybrid) were present in both treatments. The number of repetitions (nucellar seedlings) from apomictic hybrids varied between two and 25. Eight-year-old trees (163 total) were grown individually in $17-\mathrm{L}$ pots with a sterilized substrate mix $(50 \%$ peat, $30 \%$ coconut fiber, $15 \%$ sand, and $5 \%$ perlite) and placed in a screenhouse at IVIA according to a completely randomized design. Salt treatments were applied for 5 years (2004-08) between June and September with three irrigations per week of $500 \mathrm{~mL}$ per plant. The $\mathrm{NaCl}$ concentration in the irrigant was gradually increased during 2 weeks to $25 \mathrm{~mm}\left[4 \mathrm{dS} \cdot \mathrm{m}^{-1} ; \mathrm{pH}\right.$ 7.85; conductivity meter (HI9033 multirange; Hanna Instruments, Smithfield, RI)]. Plants in control conditions received the same irrigation regime using tap water $\left(1.4 \mathrm{dS} \cdot \mathrm{m}^{-1}, \mathrm{pH} 7.43\right.$; $106 \mathrm{mg} \cdot \mathrm{L}^{-1} \mathrm{Cl}^{-}, 158 \mathrm{mg} \cdot \mathrm{L}^{-1} \mathrm{SO}_{4}{ }^{2-}, 250 \mathrm{mg} \cdot \mathrm{L}^{-1} \mathrm{CO}_{3} \mathrm{H}^{-}, 115$ $\mathrm{mg} \cdot \mathrm{L}^{-1} \mathrm{NO}_{3}{ }^{-}, 138 \mathrm{mg} \cdot \mathrm{L}^{-1} \mathrm{Ca}^{2+}, 43 \mathrm{mg} \cdot \mathrm{L}^{-1} \mathrm{Mg}^{2+}, 62 \mathrm{mg} \cdot \mathrm{L}^{-1} \mathrm{Na}^{+}$, $2 \mathrm{mg} \cdot \mathrm{L}^{-1} \mathrm{~K}^{+}$). Both control and salinity-treated plants received the same pest, disease, and weed control, fertilization, and pruning work. Fertilizer was proportioned automatically by mixing in a 1:100 proportion the stock solution A $(200 \mathrm{~mm}$ $\mathrm{NH}_{4} \mathrm{H}_{2} \mathrm{PO}_{4}$ ) and solution $\mathrm{B}$. The stock solution B contained 12 $\mathrm{M} \mathrm{Ca}\left(\mathrm{NO}_{3}\right)_{2}, 2.6 \mathrm{M} \mathrm{KNO}_{3}, 36 \mathrm{~g} \cdot \mathrm{L}^{-1}$ iron chelate (Sequestrene 138 Fe; Syngenta, Madrid, Spain), and 5\% microelement solution. This solution contained $0.3 \mathrm{~mm}$ copper $\mathrm{SO}_{4} .5 \mathrm{H}_{2} \mathrm{O}$, $3.1 \mathrm{~mm}$ zinc $\mathrm{SO}_{4} \cdot 7 \mathrm{H}_{2} \mathrm{O}, 109 \mathrm{~mm}$ manganese $\mathrm{Cl}_{2} \cdot 4 \mathrm{H}_{2} \mathrm{O}, 92 \mathrm{~mm}$ $\mathrm{BO}_{3} \mathrm{H}_{3}, 2 \mathrm{~mm} \mathrm{NH}_{4} \mathrm{MoO}_{4}$, and $0.4 \mathrm{~mm} \mathrm{~V}_{2} \mathrm{O}_{5}$. A record of weather data variables including temperature and relative humidity measured under the net was obtained from the Moncada meteorological station located at IVIA (Supplemental Fig. 1).

Trait evaluation. Four yield-related traits and 25 vegetative and physiological traits were evaluated for each plant. Eighteen of these traits were measured during the 5 experimental years under control and salinity conditions. The following fruit-yield traits were evaluated annually between October and November ['Hashimoto' Satsuma mandarin collection period (Soler, 1999)]: fruit number per plant (FN); mean fruit weight per plant (FW), measured as the average weight (grams) of 10 randomly sampled fruit; and total yield per plant (TFW), measured as the weight (kilograms) of all fruit produced per plant. The total accumulated production per plant (AcTFW), measured as the total fruit weight (kilograms) produced during the 5 experimental years (2004-08), was also measured.

The 10 randomly sampled fruit per tree also were evaluated every year for the following internal and external fruit-quality traits: fruit diameter [FD (millimeters)] was measured in the transversal section; rind thickness [RT (millimeters)], including flavedo and albedo, was measured in the transversal section; juice volume (milliliters) was quantified as the volume of juice without pulp; acidity $(\mathrm{pH})$ was measured with a digital $\mathrm{pH}$ meter (PH25; Crinson, Barcelona, Spain); and total soluble solids (percent) was measured with a digital refractometer (Pallete PR-101; Atago, Tokyo, Japan).

Three fully developed leaves per plant were sampled from vegetative spring shoots to measure the following leaf characteristics after each yearly saline treatment period (June to 
September): final leaf fresh weight [LFW $f$ (grams)]; final leaf dry weight $\left[\mathrm{LDW} f\right.$ (grams)] measured in samples dried at $100^{\circ} \mathrm{C}$ for $3 \mathrm{~d}$; accumulated dry matter percentage (\%DMA) calculated as the difference between leaf dry weight at the beginning and at the end of salt treatment $\left[\% \mathrm{DMA}=\left(\mathrm{LDW}_{f}-\mathrm{LDW}_{i}\right) \times\left(100 / \mathrm{LDW}_{i}\right)\right]$; final leaf water content [LWC $f$ (grams)] calculated as the difference between $\mathrm{LFW}_{f}$ and $\mathrm{LDW}_{f}$; leaf area [LA (square centimeter)] measured with a leaf area quantifier (LI-3100C area meter; LI-COR, Lincoln, NE); leaf color parameters LCL*, $\mathrm{LCa}^{*}$, and $\mathrm{LCb}^{*}$ defined by Hunter coordinates $\left(\mathrm{L}^{*}, \mathrm{a}^{*}, \mathrm{~b}^{*}\right)$ arranged in a Cartesian system, where $\mathrm{a}^{*}(x$-axis) varies in a green/red scale $(-60$ to +60$), \mathrm{b}^{*}(y$-axis) varies in a blue/yellow scale $(-60$ to +60$)$, and $L^{*}$ represents brightness in a black/white range (0 to 100) (CR-200 colorimeter; Konica Minolta, Basildon, U.K.); and leaf color parameters $\mathrm{Cr}^{*}$ and Hue* defined by the cylindrical coordinate system $\left(L^{*}, C^{*}, h\right)$, where $\mathrm{Cr}^{*}$ (chroma) represents color intensity (0 to 60$)\left\{\mathrm{Cr}^{*}=\sqrt{ }\left[\left(\mathrm{a}^{*}\right)^{2}\right.\right.$ $\left.\left.+\left(\mathrm{b}^{*}\right)^{2}\right]\right\}$ and Hue* (hue angle) represents leaf color $\left(0^{\circ}\right.$ to $\left.360^{\circ}\right)$ [hue* $\left.=\tan ^{-1}\left(\mathrm{~b}^{*} / \mathrm{a}^{*}\right)\right]$ (HunterLab, 1996). The trait increment (for LFW, LDW, and LWC) at the end of the treatment (dTrait) also was calculated each year.

The foliar concentration (milligrams per liter) of $\mathrm{Cl}^{-}$was evaluated (Model 926 chloride analyzer; Sherwood Scientific, Cambridge, U.K.) at the end of each saline treatment period (June to September) using a random sample of three leaves per plant from the vegetative spring shoots (Gilliam, 1971). The foliar concentrations (percentage) of $\mathrm{Na}^{+}, \mathrm{Ca}^{2+}, \mathrm{Mg}^{2+}, \mathrm{K}^{+}$, and phosphorus were evaluated by inductively coupled plasma analysis at G.E. Cota.2 (Valencia, Spain) only for 2005.

At the end of the experiment in 2008, all plants (12-year-old trees) were pulled up, cleaned, and dissected to evaluate the following plant growth traits: trunk diameter [TrunkD (millimeters)] measured $2 \mathrm{~cm}$ above the graft line (using a digital caliper); total plant weight (kilograms); foliage weight (kilograms) measured above the graft line; rootstock weight (kilograms) the weight of the roots and trunk below the graft line; and the root weight [RootW (kilograms)]. Four leaf traits were measured only at the end of the experiment: leaflet fresh weight [LFWhj (grams)]; rachis fresh weight [LFWrq (grams)]; leaflet dry weight [LDWhj (grams)]; and rachis dry weight [LDWrq (grams)].

RoOTSTOCK GENOTYPING. Genomic DNA was extracted from the bark tissue below the graft union in each plant according to the protocol of Ruiz et al. (2000) with the following minor modifications. One piece of bark $(1 \times 0.5 \mathrm{~cm})$ was homogenized in liquid $\mathrm{N}_{2}$, and an additional ethanol wash was performed before resuspending the DNA pellet. Polymerase chain reaction (PCR) conditions were specific for each marker, and the resulting product was analyzed by electrophoresis in sequencingtype $10 \%$ polyacrylamide gels and revealed by silver staining as described in Ruiz et al. (2000). A set of five primer pairs was used to detect sequence characterized amplified regions targeting the following salinity tolerance candidate genes, all involved in ion $\mathrm{Na}^{+}$or $\mathrm{Cl}^{-}$homeostasis: SOS1 and SOS2 [salt overly sensitive primers were derived from those used in Villalta et al. (2008)]; NHX1 $\left[\mathrm{Na}^{+} / \mathrm{H}^{+}\right.$exchanger primers designed from citrus cDNA sequence AY028416 at the National Center for Biotechnology Information (Porat et al., 2002)]; CCC [cation chloride cotransporter primers designed from the citrus chloride cotransporter DNA sequence kindly provided by J.M. Colmenero-Flores (Colmenero-Flores et al., 2007)]; and Ethrec (ethylene receptor), whose primers were obtained from the
cDNA sequence AF092088 (C. sinensis putative ethylene receptor mRNA). In the case of CCC, four segregating alleles were revealed after $A l u \mathrm{I}$ digestion of PCR products, obtaining a cleavage amplified polymorphism marker. These salt tolerance candidate genes were located at the following linkage groups: $10+5 \mathrm{~b}$ (SOS1 and NHX1), $8+6$ (SOS2), 7 (CCC), and 3 (Ethrec), as reported by Bernet et al. (2010) and Raga et al. (2012). The identity of the polymorphic amplification products was previously checked by sequence analysis. A citrus primer list is available for scientific purposes only at IVIA Genetic Laboratory (Asins et al., 2009).

Statistical and genetic analyses. The fixed effects for rootstock $\mathrm{G}, \mathrm{E}$, year $(\mathrm{Y})$, and all their possible interactions [i.e., genotype per treatment $(\mathrm{G} \times \mathrm{E})$, genotype per year $(\mathrm{G} \times \mathrm{Y})$, treatment per year $(\mathrm{E} \times \mathrm{Y})$, and genotype per treatment per year $(\mathrm{G} \times \mathrm{E} \times \mathrm{Y})$ ] were analyzed by a repeated measures approach using trees (within each genotype and treatment) as a random subject factor and first-order autoregressive covariance structure between measurements taken from the same tree over the years. Pearson's correlation analyses between fruit yield parameters and all evaluated traits were studied under control and salinity conditions using the 13 apomictic hybrids included in both treatments in all years (InfoStat, 2004). Considering rootstocks as a random effects factor, broad-sense heritability $\left(\mathrm{H}^{2}\right)$ was estimated for all traits evaluated in 2008 only for nucellar rootstocks (repetitions) derived from apomictic $\mathrm{V} \times \mathrm{P}$ hybrids under control $\left(\mathrm{H}^{2} \mathrm{c}\right)$ or salinity $\left(\mathrm{H}^{2} \mathrm{~s}\right)$ conditions based on the genotypic $\left(\mathrm{V}_{\mathrm{G}}\right)$ and environmental $\left(\mathrm{V}_{\mathrm{E}}\right)$ variance estimators calculated by minimum variant quadratic unbiased estimator, as previously reported (Villalta et al., 2007).

Associations between parental alleles at candidate genes and means per treatment for traits were studied using the KruskalWallis procedure in MapQTL 6 (van Ooijen, 2009). All V $\times \mathrm{P}$ plants were considered taking into account their genotypes and nucellar or self-pollination origins. The significance level for candidate genes was fixed at $P \leq 0.05$.

\section{Results}

A significant effect $(P \leq 0.05)$ of the rootstock genotype and treatment was found for most fruit yield and quality traits (Table 1). Salinity decreased yield and juice volume, but improved two quality traits by $\approx 6 \%$ (TSS and RT). Year effects were highly significant in most cases.

Salinity greatly reduced tree growth and accumulated fruit yield. Leaf concentrations of $\mathrm{Cl}^{-}$and $\mathrm{Na}^{+}$increased strongly (215\% and $149 \%$, respectively). No significant rootstock effect on leaf $\mathrm{Cl}^{-}$concentration was detected in contrast to that for leaf $\mathrm{Na}^{+}$concentration. A significant $\mathrm{G} \times \mathrm{E}$ interaction was found for this trait, suggesting that the rootstock effect depends on the presence of salinity (i.e., differences among rootstocks for $\mathrm{Na}^{+}$ translocation to the leaf were not predicted from control conditions). Few traits showed a significant $\mathrm{G} \times \mathrm{E}$ interaction (differential rootstock behavior) that did not depend on the year (no significant $\mathrm{G} \times \mathrm{E} \times \mathrm{Y}$ ); these included FW, TFW, and LWC. There were two additional traits for which a $\mathrm{G} \times \mathrm{E}$ interaction was significant (AcTFW and leaf $\left[\mathrm{Na}^{+}\right]$), but these were evaluated in only 1 year. Estimates for trait heritability ranged from low to very low (Table 1). In general, plants under saline treatment had smaller estimates than those under control conditions. Exceptions to this included pH, LDW, LDWrq, LFWrq, and TrunkD. 
Table 1. Probability values of rootstock effects from the three-way repeated analyses using nucellar rootstocks from 13 apomictic hybrids between 'Volkamer' lemon and 'Rubidoux' trifoliate orange. ${ }^{\mathrm{z}}$

\begin{tabular}{|c|c|c|c|c|c|c|c|c|c|c|}
\hline Trait $^{\mathrm{y}}$ & $\mathrm{G}^{\mathrm{x}}$ & $E$ & $\mathrm{C} \rightarrow \mathrm{S}$ & $\mathrm{G} \times \mathrm{E}$ & $\mathrm{Y}^{\mathrm{w}}$ & $\mathrm{G} \times \mathrm{Y}$ & $\mathrm{E} \times \mathrm{Y}$ & $\mathrm{G} \times \mathrm{E} \times \mathrm{Y}$ & $\mathrm{H}^{2} \mathrm{c}$ & $\mathrm{H}^{2} \mathrm{~s}$ \\
\hline$\overline{\mathrm{FN}}$ & $<0.0001$ & - & - & - & $<0.0001$ & - & - & - & 0.29 & 0.18 \\
\hline FW & 0.0016 & 0.0001 & -6 & 0.0018 & $<0.0001$ & - & - & - & 0.21 & 0.10 \\
\hline TFW & $<0.0001$ & $<0.0001$ & -14 & 0.0251 & $<0.0001$ & 0.0113 & 0.0291 & - & 0.40 & 0.15 \\
\hline TSS & $<0.0001$ & 0.0041 & 6 & - & $<0.0001$ & - & - & - & 0.18 & 0.10 \\
\hline JV & 0.0302 & 0.0002 & -3 & 0.0309 & $<0.0001$ & 0.0002 & - & 0.0187 & 0.09 & 0.06 \\
\hline $\mathrm{pH}$ & 0.0003 & - & - & - & $<0.0001$ & $<0.0001$ & - & - & - & 0.21 \\
\hline LDWf & - & - & - & - & $<0.0001$ & - & - & - & - & 0.18 \\
\hline LDWhj & - & - & - & - & . & . & . & . & - & - \\
\hline LDWrq & - & - & - & - & . & . & . & . & - & 0.10 \\
\hline LWCf & - & - & - & 0.0401 & $<0.0001$ & - & $<0.0001$ & - & 0.03 & 0.08 \\
\hline LA & - & 0.0351 & 7 & - & $<0.0001$ & 一 & $<0.0001$ & 一 & 0.02 & - \\
\hline $\mathrm{LCa}^{*}$ & 0.0315 & - & - & - & $<0.0001$ & - & 0.0010 & - & 0.13 & 0.08 \\
\hline $\mathrm{LCb}^{*}$ & - & - & - & - & $<0.0001$ & 0.0089 & 0.0006 & - & 0.19 & - \\
\hline $\mathrm{LCL}^{*}$ & 0.0145 & - & - & - & $<0.0001$ & - & 0.0025 & - & 0.19 & - \\
\hline $\mathrm{Cr}^{*}$ & 0.0270 & - & - & - & $<0.0001$ & 0.0052 & 0.0014 & - & 0.26 & 0.01 \\
\hline Hue* & - & 0.0102 & -1 & - & $<0.0001$ & 一 & 0.0055 & - & - & - \\
\hline PLTW & $<0.0001$ & 0.0001 & -27 & - & . & . & . & . & 0.38 & 0.17 \\
\hline FoW & $<0.0001$ & $<0.0002$ & -28 & - & . & . & . & . & 0.45 & 0.17 \\
\hline RTSW & 0.0003 & 0.0023 & -25 & - & . & . & . & . & 0.26 & 0.17 \\
\hline RootW & 0.0002 & 0.0023 & -27 & - & . & . & . & . & 0.30 & 0.19 \\
\hline
\end{tabular}

"'Hashimoto' Satsuma mandarin was the scion in all cases. G, E, and Y correspond to genotypic, salinity treatment (25 mm NaCl), and year effects, respectively. Genotype per treatment $(\mathrm{G} \times \mathrm{E})$, genotype per year $(\mathrm{G} \times \mathrm{Y})$, treatment per year $(\mathrm{E} \times \mathrm{Y})$, and genotype per treatment per year $(\mathrm{G} \times \mathrm{E} \times \mathrm{Y})$ are the interactions. The positive or negative increment of trait mean when the treatment was significant is indicated as a percentage in the transition from a control to the saline condition $(\mathrm{C} \rightarrow \mathrm{S}) . \mathrm{H}^{2} \mathrm{c}$ and $\mathrm{H}^{2} \mathrm{~s}$ are sensu lato heritability estimates for control and salinity conditions, respectively.

${ }^{\mathrm{y}} \mathrm{FN}=$ fruit number; $\mathrm{FW}=$ mean fruit weight; TFW = total yield; AcTFW = total accumulated fruit yield; TSS = soluble solids concentration; JV = juice volume; RT = rind thickness; FD = fruit diameter; $\mathrm{pH}=$ fruit juice acidity; LDWf = final leaf dry weight; LDWhj = leaflet dry weight; LDWrq = rachis dry weight; $\%$ DMA = accumulated dry matter percentage; LFWf = final leaf fresh weight; LFWhj = leaflet fresh weight; LFWrq = rachis fresh weight; $\mathrm{LWCf}=$ final leaf water content; $\mathrm{LA}=$ leaf area; $\mathrm{LCa}^{*}, \mathrm{LCb}^{*}$, and LCL* = leaf color parameter (defined by Hunter a*, $\mathrm{b}^{*}$ and $\mathrm{L}^{*}$, respectively); $\mathrm{Cr} *=$ leaf color function $\sqrt{ }\left(\mathrm{a}^{*}\right)^{2}+\left(\mathrm{b}^{*}\right)^{2}$; Hue* = leaf index $\tan ^{-1}\left(\mathrm{~b}^{*} / \mathrm{a}^{*}\right)$; PLTW $=$ total plant weight; FoW $=$ foliage weight; RTSW = rootstock weight; RootW = root weight; TrunkD = trunk diameter; $\mathrm{Cl}, \mathrm{Na}, \mathrm{Ca}, \mathrm{Mg}, \mathrm{K}$, and $\mathrm{P}=$ foliar concentrations of $\mathrm{Cl}^{-}$, $\mathrm{Na}^{+}$, $\mathrm{Ca}^{2+}, \mathrm{Mg}^{2+}, \mathrm{K}^{+}$, and phosphorus, respectively.

${ }^{x}$ Dashes indicate data not significant.

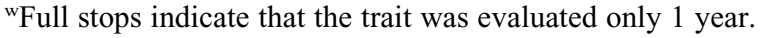

Considering accumulative fruit yield under salinity as the most relevant criteria for selection of rootstocks conferring salt tolerance, only $5 \%$ of $\mathrm{V} \times \mathrm{P}$ hybrids conferred higher yield than the 'Volkamer' lemon parent when used as rootstock (Fig. 1B) Noteworthy, differences between control genotypes were larger under control than under salinity condition (Figs. 1A and 1B). If only the last 3 years of evaluation are considered (2006-08), and $P>0.02$ is chosen as significant, then TFW is strongly correlated with the FN component (Table 2), which is quite consistently related to TSS, particularly under salinity. The FW component is related to FD, JV, and RT, and indirectly to TSS and FN, under both control and salinity conditions. Correlation coefficients for traits evaluated under control conditions were usually higher than the same traits under salinity conditions. A significant correlation between both conditions with respect to fruit traits was found only for AcTFW (0.79) and FN (0.73) in 

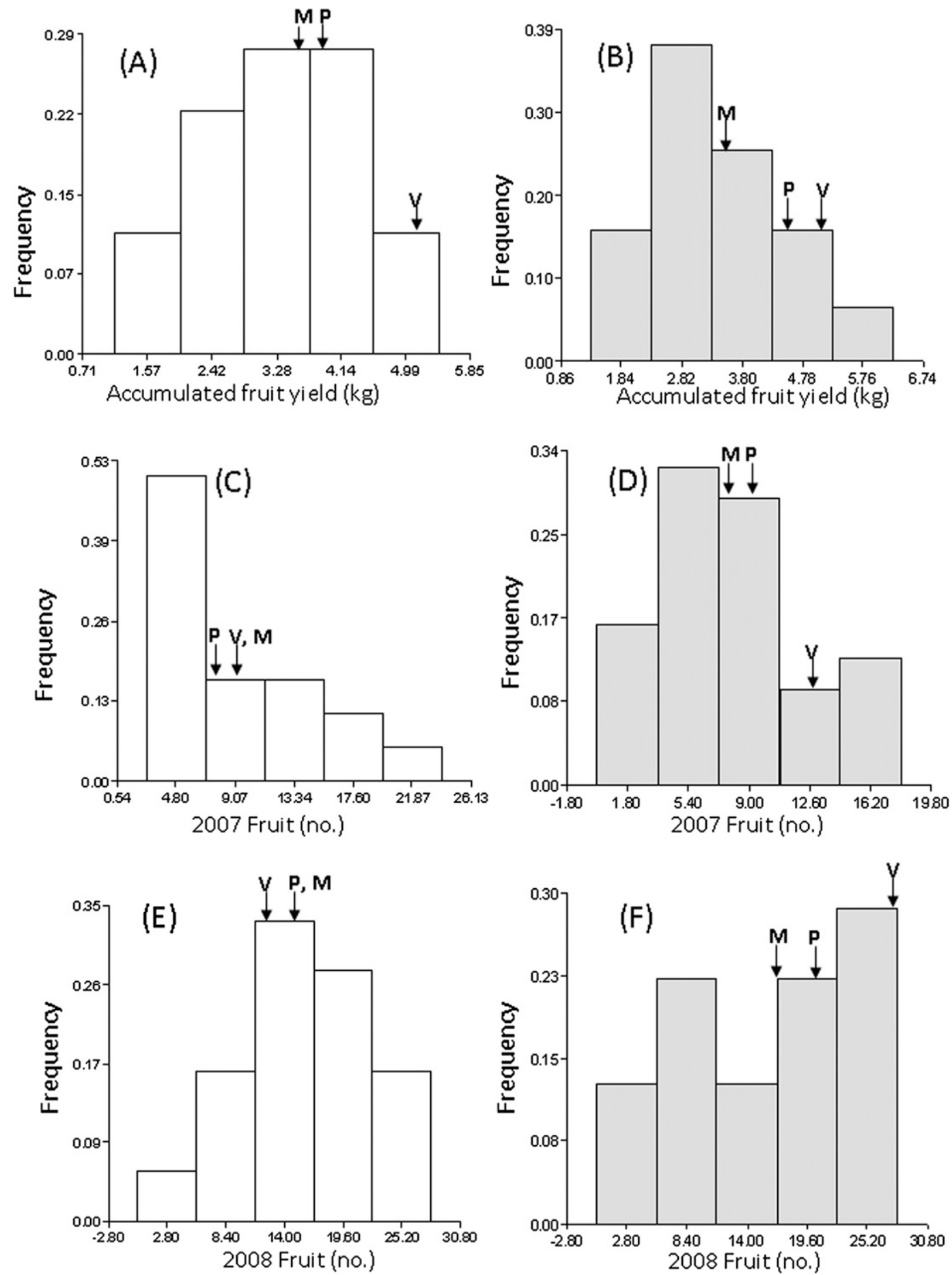

Fig. 1. Frequency distributions of (A-B) total accumulated fruit yield (AcTFW) and (C-F) fruit number (FN) of 'Hashimoto' Satsuma mandarin grafted on nucellar seedlings from hybrids between 'Volkamer' lemon and 'Rubidoux' trifoliate orange for the two last yielding years under control $(\mathbf{A}, \mathbf{C}$, and $\mathbf{E})$ and salinity $(\mathbf{B}, \mathbf{D}$, and $\mathbf{F}$ ) conditions. The phenotypic means of the population (M) and the control genotypes ['Volkamer' lemon (V) and 'Flying Dragon' trifoliate orange (P)] are indicated.

2007, despite the FN distribution differences between both treatments (Figs. 1C and 1D).

Fruit yield traits did not show a consistent, significant correlation with any non-fruit (vegetative) trait. Leaf $\left[\mathrm{Cl}^{-}\right]$ appeared related to $\mathrm{FN}$ and indirectly to $\mathrm{FW}$ under control and salinity conditions in 2007 and 2006, respectively, whereas leaf $\left[\mathrm{Na}^{+}\right]$was only related to TFW and FN in 2006. The leaf color hue* index also appeared related to fruit yield traits under control (2006 and 2007) and salinity (2007) conditions.

The poor consistency of correlations through all experimental years indicated the importance of the year effect. Thus, the distribution of FN (under both the control and salinity conditions) changed depending on the year, as shown in Figure 1C-E for the last 2 consecutive years (2007 and 2008). 

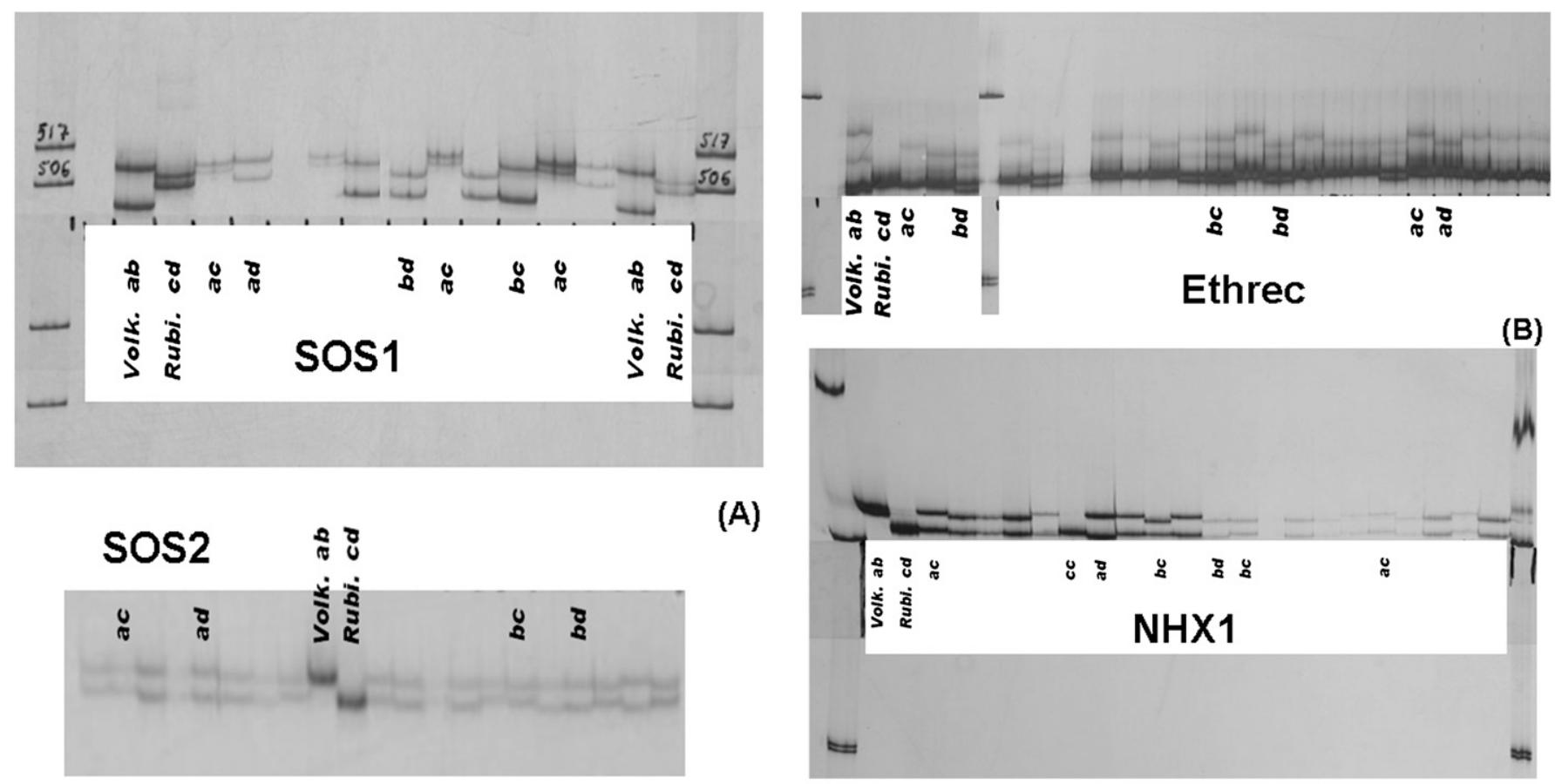

(A)
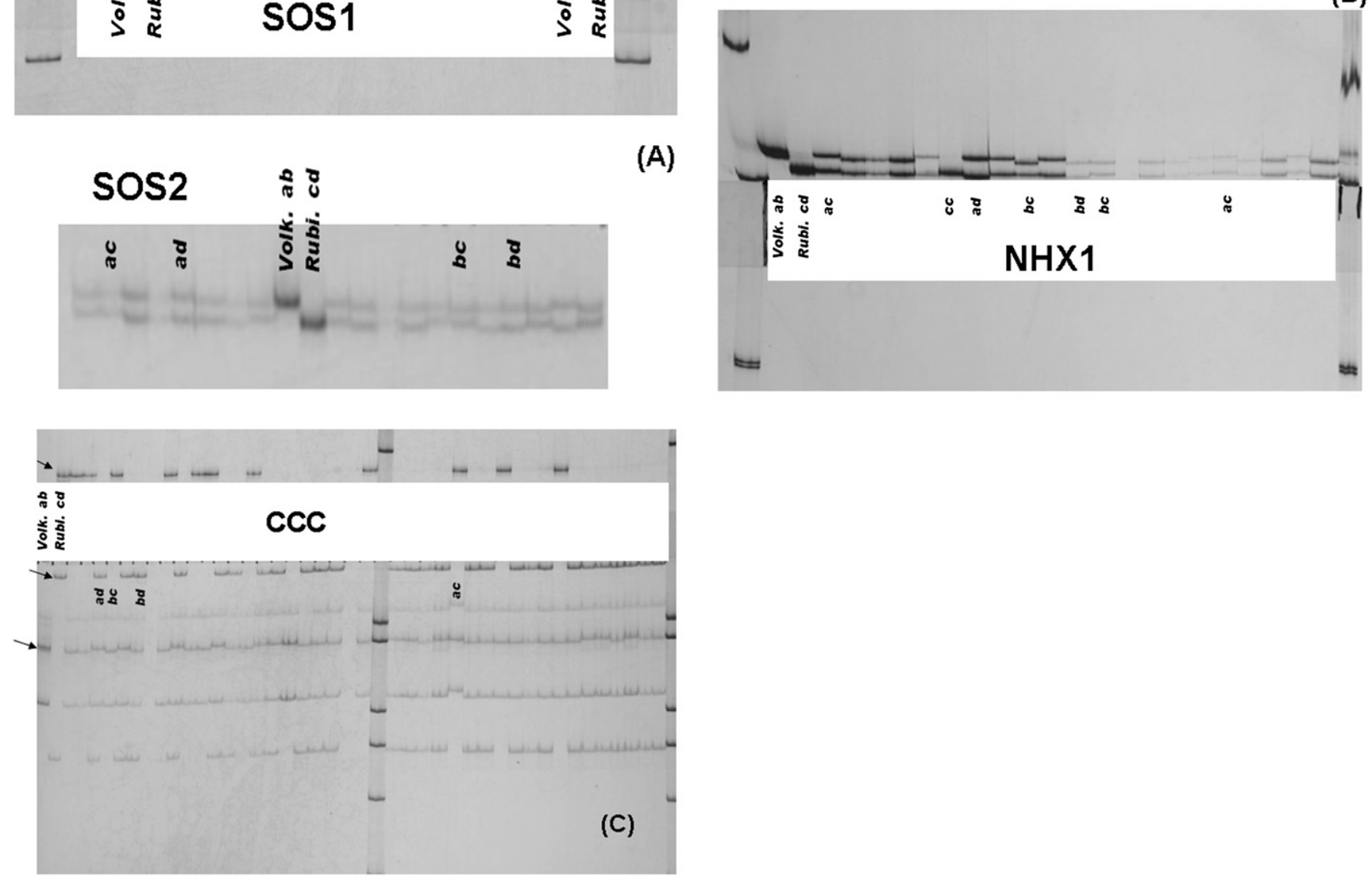

Fig. 2. Silver-stained gel electrophoresis of markers developed for (A) salt overly sensitive genes SOS1 and SOS2; (B) Ethrec (ethylene receptor) and the $\mathrm{Na}^{+} / \mathrm{H}^{+}$ exchanger gene NHX1; and (C) CCC (cation chloride cotransporter) of V $\times$ P hybrids between between 'Volkamer' lemon (V) and 'Rubidoux' trifoliate orange (P). Four possible genotypes of the $\mathrm{V} \times \mathrm{P}$ progeny are indicated as $a b, a c, b c$, and $b d$, where $a$ and $b$ correspond to the alleles of 'Volkamer' lemon (Volk.) and $c$ and $d$ correspond to those of 'Rubidoux' trifoliate orange (Rubi.).

Four genotypes, named $a c, a d, b c$, and $b d$, were observed for the hybrids derived from the cross between 'Volkamer' lemon $(a b)$ and 'Rubidoux' trifoliate orange $(c d)$ at each of the five candidate gene loci (Fig. 2). Similar to the results from correlation analyses, candidate genes were associated with some traits only in certain years, except for TFW, which was consistently associated with SOS1 (Fig. 2A) under control conditions $\left(1.4 \mathrm{dS} \cdot \mathrm{m}^{-1}\right.$ tap water) for the 3 last experimental years (Table 3). NHX1 (Fig. 2B) was associated with fruit yield traits (FN and FW) only under control conditions. The same allele at NHX1 that correlated with higher FW7 (fruit weight in year 2007) and FW8 also correlated with higher LWC7. The same allele at SOS1 that correlated with higher FN6 and FN7 correlated with higher TFW in 2006, 2007, and 2008. Leaf $\left[\mathrm{Cl}^{-}\right]$ was found associated with CCC (Fig. 2C) and Ethrec (Fig. 2B), but only under control conditions. For Ethrec, the same allele that correlated with a higher increment for leaf water content in control (dLWC8_C) was associated with a high leaf $\left[\mathrm{Cl}^{-}\right]$. CCC was associated with LWC (but not with leaf $\left[\mathrm{Cl}^{-}\right]$) under salinity conditions. Under salinity conditions, variations for LWC were associated with 'Volkamer' lemon alleles (at CCC and SOS1), whereas 'Rubidoux' trifoliate orange alleles in the rootstock at SOS2 were associated with significant variations in leaf $\left[\mathrm{Na}^{+}\right]$in Satsuma mandarin.

\section{Discussion}

Many non-genetic factors can affect plant responses to salinity such as the composition and concentration of salts (Lauchli and Grattan, 2007), drought, irradiance, leaf temperature, atmospheric evaporative demand, soil type, and agronomic practices (Adnan, 2004; Syvertsen and Levy, 2005). We 
Table 2. Pearson correlation coefficients and probability values of significant $(P<0.02)$ correlations between fruit yield traits (last 3 years) and all evaluated traits (Corr. trait) using nucellar rootstocks from 13 apomictic hybrids between 'Volkamer' lemon and 'Rubidoux' trifoliate orange under control and salinity $(25 \mathrm{~mm} \mathrm{NaCl})$ conditions. ${ }^{z}$

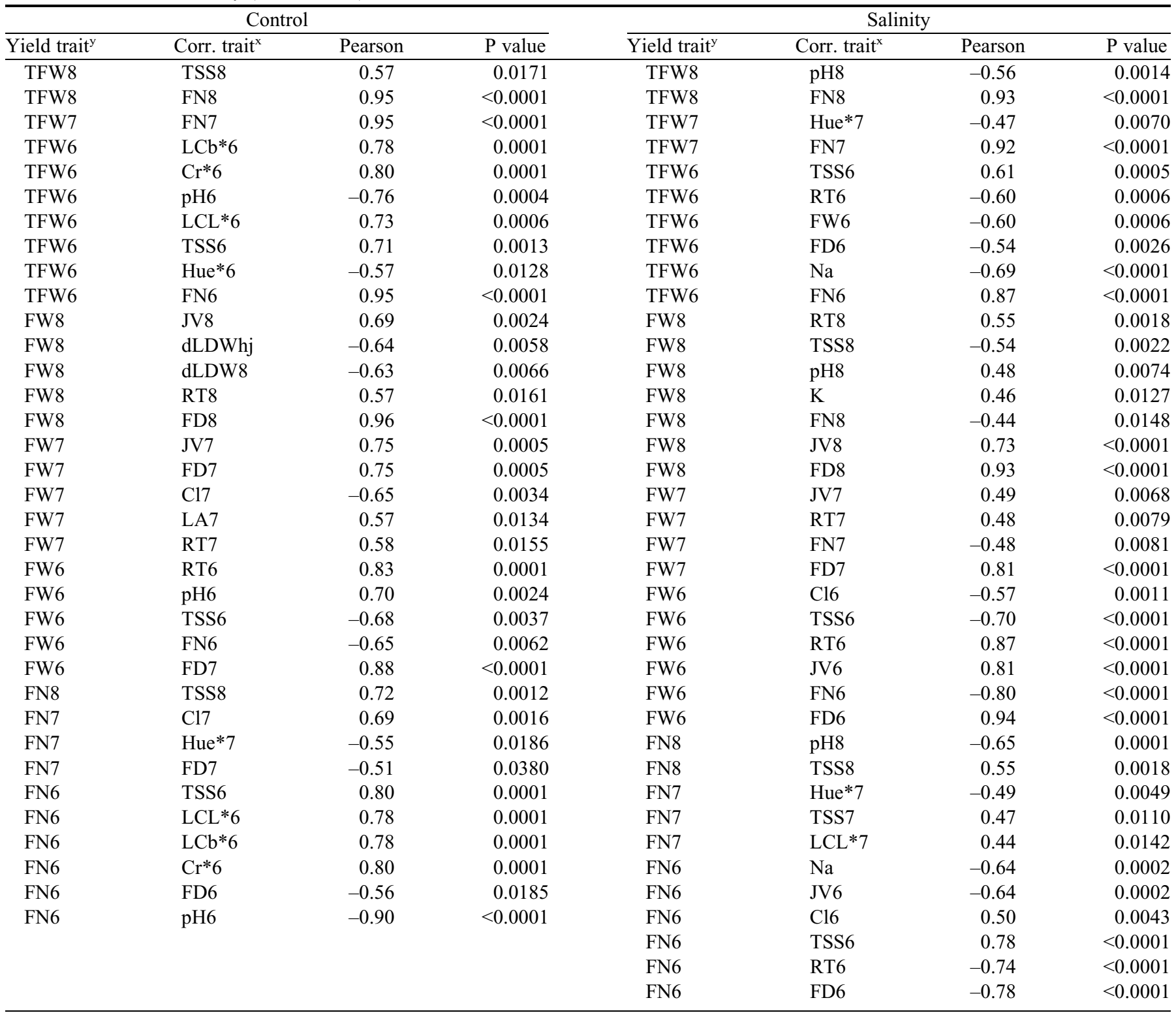

z'Hashimoto' Satsuma mandarin was the scion in all cases. The number after the trait name indicates the year of harvesting (e.g., six for 2006). ${ }^{\mathrm{y}}$ Significant yield traits: $\mathrm{FN}=$ fruit number; $\mathrm{FW}=$ mean fruit weight; TFW = total yield.

${ }^{\mathrm{x}}$ Correlated traits: $\mathrm{FN}=$ fruit number; $\mathrm{FW}=$ mean fruit weight; $\mathrm{TSS}=$ soluble solids concentration; JV = juice volume; $\mathrm{RT}=$ rind thickness; FD = fruit diameter; $\mathrm{pH}=$ fruit juice acidity; $\mathrm{dLDW}=$ increment for leaf dry weight at the end of the treatment; $\mathrm{dLDWhj}=$ increment for leaflet dry weight at the end of the treatment; $\mathrm{LA}=$ leaf area; $\mathrm{LCb}^{*}$ and $\mathrm{LCL}^{*}=$ leaf color parameters defined by Hunter $\mathrm{b}^{*}$ and $\mathrm{L}^{*}$; $\mathrm{Cr}^{*}=$ leaf color function $\sqrt{ }\left(\mathrm{a}^{*}\right)^{2}+\left(\mathrm{b}^{*}\right)^{2}$; Hue* $=$ leaf index $\tan ^{-1}\left(\mathrm{~b}^{*} / \mathrm{a}^{*}\right) ; \mathrm{Cl}, \mathrm{Na}$, and $\mathrm{K}=$ foliar concentrations $\mathrm{Cl}^{-}, \mathrm{Na}^{+}$, and $\mathrm{K}^{+}$, respectively.

experimentally tried to minimize non-genetic effects and interactions by growing plants in large pots under a screenhouse and controlling salinity with irrigation. We approached the citriculture practice by evaluating the rootstocks in terms of the fruit yield of the scion during several years. For this purpose, a population of genetically related rootstocks was grafted with the same citrus cultivar. This experimental design allowed us to genetically analyze the rootstock effects on the grafted cultivar. The approach of Tozlu et al. (1999) used a non-grafted segregating progeny derived from Citrus grandis (a sexual species not used as rootstock) and P. trifoliata. Our approach intended a more realistic evaluation of the salt tolerance conferred by the rootstock. Nevertheless, our findings, using a semihydroponic system, might differ from those that would have been obtained under real field conditions.

Highly significant year effects were obtained for most traits (Table 1). Differences among years for relative humidity and temperature existed (Supplementary Fig. S1), which might explain the year effects, at least in part. Mandarins are perennial crops with alternate-bearing, and so year effects also can be attributed to this phenomenon and interfere with the salt 
Table 3. List of significant trait candidate gene associations and corresponding genotypic means using seedlings from 13 or 32 hybrids between 'Volkamer' lemon and 'Rubidoux' trifoliate orange as rootstocks under control and salinity $(25 \mathrm{~mm} \mathrm{NaCl})$, respectively. ${ }^{\mathrm{z}}$

\begin{tabular}{lccrr}
\hline Trait & Candidate gene & \multicolumn{1}{c}{$\mathrm{K}^{*}$} & Mean a-/c- & Mean b-/d- \\
\hline Cl8_C & CCC_V & $4.667 *$ & 11.678 & 15.471 \\
LWC8_S & CCC_R & $4.539 *$ & 1.687 & 1.438 \\
AcTFW8_C & NHX1_R & $4.000 *$ & 4.073 & 3.107 \\
Na_C & NHX1_R & $4.554 *$ & 0.068 & 0.110 \\
FW8_C & NHX1_V & $4.303 *$ & 63.691 & 78.322 \\
FW7_C & NHX1_V & $8.163 * * *$ & 106.181 & 119.938 \\
LWC7_C & NHX1_V & $4.930 *$ & 1.304 & 1.590 \\
dLWC8_C & Ethrec_R & $3.927 *$ & 0.514 & 0.418 \\
C18_C & Ethrec_R & $4.200 *$ & 15.761 & 11.972 \\
RootW8_C & SOS1_R & $4.022 *$ & 0.585 & 0.314 \\
RTSW8_C & SOS1_R & $4.011 *$ & 0.657 & 0.379 \\
PLTW8_C & SOS1_R & $4.930 *$ & 0.425 & 0.311 \\
FoW8_C & SOS1_R & $4.917 *$ & 1.082 & 0.689 \\
TFW8_C & SOS1_R & $4.303 *$ & 1.362 & 0.930 \\
TFW7_C & SOS1_R & $5.239 *$ & 1.362 & 0.683 \\
FN7_C & SOS1_R & $4.592 *$ & 12.187 & 6.270 \\
TFW6_C & SOS1_R & $6.302 *$ & 1.200 & 0.797 \\
FN6_C & SOS1_R & $6.267 *$ & 15.708 & 9.336 \\
LWC8_S & SOS1_V & $4.539 *$ & 1.438 & 1.687 \\
Na_S & SOS2_R & $5.272 *$ & 0.299 & 0.394 \\
\hline
\end{tabular}

z'Hashimoto' Satsuma mandarin was the scion in all cases. The letters $\mathrm{R}$ and $\mathrm{V}$ after the marker locus refer to 'Rubidoux' trifoliate orange (c and d) or 'Volkamer' lemon (a and b) alleles, respectively (see Fig. 2). Means of hybrids designated a- and b- correspond to those genotypes receiving allele $\mathrm{a}(\mathrm{ac}$ and $\mathrm{ad})$ or $\mathrm{b}$ ( $\mathrm{bc}$ and $\mathrm{bd}$ ), respectively, from 'Volkamer' lemon. Similarly, genotypic means c- and d- correspond to hybrids receiving allele c (ac and bc) or d (ad and bd) from 'Rubidoux' trifoliate orange, respectively. $\mathrm{K}$ is the Kruskal-Wallis statistic provided by MapQTL 6 software (van Ooijen, 2009). The number after the trait name indicates the year of harvesting (e.g., six for 2006). Control $\left(1.4 \mathrm{dS} \cdot \mathrm{m}^{-1}\right)$ or salinity $\left(4 \mathrm{dS} \cdot \mathrm{m}^{-1}\right)$ conditions are indicated with the suffix _C or _S after the trait code. *Significant at $5 \%$; $* * *$ significant at $0.5 \%$.

${ }^{y}$ Salt tolerance-related traits: $\mathrm{FN}=$ fruit number; $\mathrm{FW}=$ mean fruit weight; TFW = total yield; AcTFW = total accumulated fruit yield; $\mathrm{LWC}=$ final leaf water content; PLTW $=$ total plant weight; FoW = foliage weight; RTSW = rootstock weight; RootW = root weight; Cl and $\mathrm{Na}=$ foliar concentrations of $\mathrm{Cl}^{-}$and $\mathrm{Na}^{+}$, respectively.

${ }^{\mathrm{x}}$ Candidate gene for: SOS1 and SOS2 (salt overly sensitive), NHX1 $\left(\mathrm{Na}^{+} / \mathrm{H}^{+}\right.$exchanger), $\mathrm{CCC}$ (cation chloride cotransporter), and Ethrec (ethylene receptor).

tolerance response in terms of fruit yield. For these reasons, a multiyear approach was used.

A general reduction of tree vegetative growth by $\approx 30 \%$ was observed under salinity conditions (Table 1). Similar effects have been reported in grafted citrus crops with reductions in plant height, canopy volume, and trunk diameter (GarcíaSánchez et al., 2006; Grieve et al., 2007). Our results showed that the rootstock greatly influenced fruit traits of the grafted cultivar (in agreement with the citrus bibliography), but no single vegetative trait could fully predict fruit yield. Heritability estimates of rootstock-mediated effects on fruit yield under salinity (Table 1) were low, 0.18 at most, below those reported for tomato (Solanum lycopersicum) rootstocks (0.3 in Estañ et al., 2009). In general, trait heritabilities were higher under control than under salinity conditions, which suggested that the rootstock segregant population had larger genetic variability (i.e., more genes involved and/or larger effects on the traits) under control conditions than under salinity conditions. However, there were exceptions, because traits might be related to physiological mechanisms of salinity tolerance, including LDW, LDWrq, \%DMA, LFWhj, LFWrq, LWC, and TrunkD. All these exceptional traits were related to vegetative growth and the osmotic stress response (Munns and Tester, 2008).

Citrus salt tolerance is related to the capacity to restrict $\mathrm{Cl}^{-}$ transport from root to leaves (Levy and Syvertsen, 2004; Maas, 1993; Ream and Furr, 1976). Heritability estimates of the leaf concentration for both toxic ions clearly decay under salinity, primarily as a result of non-genetic components. It is deduced from Table 1 that genetic variability $\left(\mathrm{H}^{2}\right)$ to improve scion leaf $\left[\mathrm{Na}^{+}\right]$is available at the segregating rootstock population, but apparently not for $\left[\mathrm{Cl}^{-}\right]$. Therefore, is scion leaf $\left[\mathrm{Cl}^{-}\right]$a good criterion to select $\mathrm{V} \times \mathrm{P}$ rootstocks for salt tolerance? The $\left[\mathrm{Cl}^{-}\right]$ is directly related to $\mathrm{FN}(0.69)$ and indirectly related to $\mathrm{FW}$ $(-0.65)$ under control conditions (Table 2). Under salinity conditions, correlation coefficients decreased to 0.50 and -0.57 for $\mathrm{FN}$ and $\mathrm{FW}$, respectively. Therefore, the value of leaf $\left[\mathrm{Cl}^{-}\right]$ to predict salt tolerance in the $\mathrm{V} \times \mathrm{P}$ population is low. For candidate gene analyses, the $\mathrm{CCC}$ of the citrus rootstock is only associated with leaf $\left[\mathrm{Cl}^{-}\right]$under control conditions (Table 3); it does not appear useful to predict leaf $\left[\mathrm{Cl}^{-}\right]$under salinity in the $\mathrm{V} \times \mathrm{P}$ progeny. Chloride is an essential plant micronutrient that participates in osmoregulation, cell elongation, vacuolar turgor regulation, membrane potential stabilization, and $\mathrm{pH}$ regulation (White and Broadley, 2001). The double role (nutritious/toxic) of $\mathrm{Cl}^{-}$in citrus plants might explain why different genes control leaf $\left[\mathrm{Cl}^{-}\right]$depending on the absence/presence of salinity. However, the lack of a significant association of CCC genotypes with leaf $\left[\mathrm{Cl}^{-}\right]$variations under salinity does not prove that $\mathrm{CCC}$ is not involved in salinity responses. The large nongenetic variability and/or a decay of its putative individual contribution under salinity conditions might explain the failure to detect it under salinity conditions.

Considering the scion leaf $\left[\mathrm{Na}^{+}\right]$as a good criterion to early select rootstocks for salt tolerance, $P$. trifoliata was reported as an efficient $\mathrm{Na}^{+}$excluder at low salinities (Sykes, 2011; Walker, 1986), similar to some of its hybrids (Sykes, 1992). This is in agreement with the association of leaf $\left[\mathrm{Na}^{+}\right]$and AcTFW with NHX1 under control conditions (Table 3 ), in which high yield and low leaf $\left[\mathrm{Na}^{+}\right]$are related to the same 'Rubidoux' allele, suggesting a putative contribution of the citrus rootstock NHX1 to the variation of both scion traits. There is increasing evidence to show that NHX antiporters regulate the homeostasis of $\mathrm{K}^{+}$ and $\mathrm{pH}$ in intracellular membranes under normal and saline conditions (Barragán et al., 2012; Bassil et al., 2011; Leidi et al., 2010; Venema et al., 2003; Yamaguchi et al., 2013). The tonoplast vacuole NHX1 antiporter participates in Arabidopsis thaliana salt tolerance by compartmentalization of $\mathrm{Na}^{+}$(Leidi et al., 2010; Munns and Tester, 2008). However, under salinity conditions, the association between AcTFW with NHX1 was not detected, and leaf $\left[\mathrm{Na}^{+}\right]$was significantly associated with 'Rubidoux' trifoliate orange alleles at SOS2 (Table 3).

The 'Rubidoux' alleles of the salt tolerance candidate gene SOS1 were consistently associated with fruit yield under control conditions (Table 3 ). As it has been recently reviewed by Yamaguchi et al. (2013), SOS1 appears to have several other functions that are not directly related to $\mathrm{Na}^{+}$homeostasis but to $\mathrm{pH}$ homeostasis, both in the cytosol and the vacuole of root 
cells. Noteworthy, SOS1 is also associated with root and rootstock weights (Table 3). The 'Volkamer' lemon alleles at both SOS1 and CCC were associated with LWC under salinity conditions. Therefore, maintaining the scion water content might be an important role of the citrus rootstock derived from 'Volkamer' lemon to manage excess $\mathrm{Cl}^{-}$and $\mathrm{Na}^{+}$under moderate salinity, genetically connecting the physiological mechanisms of salt tolerance defined by Munns and Tester (2008). Among the exceptional traits whose heritability estimates increased under salinity conditions, LWC showed statistical evidence of differential rootstock behavior depending on the presence of salinity [significant $\mathrm{G} \times \mathrm{E}($ Table 1)]. This result supports the hypothesis that salt tolerance in citrus depends to a great extent on water use (Moya et al., 2003; Syvertsen et al., 2010), although we found no significant genetic correlation between $\mathrm{LWC}$ and leaf $\left[\mathrm{Cl}^{-}\right]$under salinity nor control conditions. This salt tolerance strategy based on the rootstock's ability to maintain the scion water content was also found in tomato (Asins et al., 2010). Therefore, exploiting this tolerance mechanism might be useful for rootstock breeding in general.

Our results did not show a significant effect of salinity on mandarin juice $\mathrm{pH}$ (Table 1). Other citrus studies (reviewed by Navarro et al., 2010), with different experimental designs (one or two unrelated rootstocks) and different grafted cultivars, showed different salinity effects on juice $\mathrm{pH}$, either increasing (Navarro et al., 2010) or decreasing (García-Sánchez et al., 2003) juice acidity.

Significant effects of salinity on other fruit quality traits were observed. Some traits such as JV and FD were reduced, whereas others were improved such as TSS and RT (Table 1). Higher TSS under salinity stress was previously observed for other grafted citrus cultivars (Boman, 2005; Dasberg et al., 1991; García-Sánchez et al., 2003, 2006; Navarro et al., 2010). Under salinity conditions, JV was directly correlated with FW, whereas TSS was directly correlated with FN and indirectly correlated with FW. Therefore, the TSS increase could be related to the reduction in JV (and FW) as a result of reduced water availability, as found previously for a Clementine mandarin (Navarro et al., 2010). The main components of variance influencing TSS were the rootstock genotype and the year $(P<$ 0.0001; Table 1) and no significant interaction $(\mathrm{G} \times \mathrm{E}, \mathrm{G} \times \mathrm{Y}$, $\mathrm{E} \times \mathrm{Y}$, and $\mathrm{G} \times \mathrm{E} \times \mathrm{Y}$ ) was found suggesting that all genotypes increase TSS similarly under salinity. Because this is not the case for JV, other than reduction of JV could contribute to the increment of TSS under salinity. The enhancement of sucrose hydrolysis, increasing the concentrations of hexose sugars, might be involved such as was proposed under moderate water deficit stress in Satsuma mandarin (Yakushiji et al., 1996; Yukushiji et al., 1998) and 'Valencia' sweet orange (Barry et al., 2004).

Given that mandarin juice volume (and FW) showed a significant $\mathrm{G} \times \mathrm{E}$ interaction, whereas TSS did not, it seems possible to select $\mathrm{V} \times \mathrm{P}$ rootstocks that would increase TSS and maintain JV under salinity conditions. As a consequence, these rootstocks would induce earlier fruit maturation for a given grafted cultivar under salinity conditions and expand the harvesting period of citrus cultivars, which is a major goal of the citrus industry worldwide.

In conclusion, our results on the inheritance of rootstock effects on salt tolerance in the progeny of 'Vokamer' lemon agrees the hypothesis that it depends to a great extent on water use (Moya et al., 2003; Syvertsen et al., 2010). Because only a $5 \%$ of $\mathrm{V} \times \mathrm{P}$ progeny induced higher fruit yield than the salttolerant parent, and the heritabilities of rootstock effects were low, selection assisted by associated markers might be useful to obtain rootstocks that confer salt tolerance to the grafted mandarin. Salt-tolerant candidate genes SOS1 and NHX1 were associated with fruit yield traits under control conditions $\left(1.4 \mathrm{dS} \cdot \mathrm{m}^{-1}\right)$, and SOS1 and CCC were associated with LWC under salinity conditions $\left(4 \mathrm{dS} \cdot \mathrm{m}^{-1}\right)$. Results from rootstock effects on fruit quality traits suggest that rootstocks inducing early fruit maturation can be selected within the $\mathrm{V} \times \mathrm{P}$ progeny to expand the harvesting calendar in citrus under moderate salinity conditions.

\section{Literature Cited}

Adnan, A. 2004. Influence of salinity on citrus. A review paper. J. Central European Agr. 5:263-272.

Apse, M.P. and E. Blumwald. 2007. $\mathrm{Na}^{+}$transport in plants. FEBS Lett. 581:2247-2254.

Asins, M.J., M.C. Bolarín, F. Pérez-Alfocea, M.T. Estañ, C. MartínezAndújar, A. Albacete, I. Villalta, G.P. Bernet, I. Dodd, and E.A. Carbonell. 2010. Genetic analysis of physiological components of salt tolerance conferred by Solanum rootstocks. What is the rootstock doing for the scion? Theor. Appl. Genet. 121:105-115.

Asins, M.J., C. Ruiz, and G.P. Bernet. 2009. Citrus primer list. 12 May 2014. < http://www.ivia.es/ mjasins/index.html $>$.

Bañuls, M.J., M.D. Serna, F. Legaz, M. Talón, and E. Primo-Millo. 1997. Growth and gas exchange parameters of citrus plants stressed with different salts. J. Plant Physiol. 150:194-199.

Barragán, V., E.O. Leidi, Z. Andrés, L. Rubio, A. De Luca, J.A. Fernández, B. Cubero, and J.M. Pardo. 2012. Ion exchangers NHX1 and NHX2 mediate active potassium uptake into vacuoles to regulate cell turgor and stomatal function in arabidopsis. Plant Cell 24:1127-1142.

Barry, G.H., W.S. Castle, and F.S. Davis. 2004. Rootstock and plant water relations affect sugar accumulation of citrus fruit via osmotic adjustment. J. Amer. Soc. Hort. Sci. 129:881-889.

Bassil, E., M.A. Ohto, T. Esumi, H. Tajima, Z. Zhu, O. Cagnac, M. Belmonte, Z. Peleg, T. Yamaguchi, and E. Blumwald. 2011. The arabidopsis intracellular $\mathrm{Na}^{+} / \mathrm{H}^{+}$antiporters NHX5 and NHX6 are endosome associated and necessary for plant growth and development. Plant Cell 23:224-239.

Bernet, G.P., J. Fernandez-Ribacoba, E.A. Carbonell, and M.J. Asins. 2010. Comparative genome-wide segregation analysis and map construction using a reciprocal cross design to facilitate citrus germplasm utilization. Mol. Breed. 25:659-673.

Bingham, E.T., R.J. Mahler, J. Parra, and L.H. Stolzy. 1974. Longterm effects of irrigation-salinity management on a Valencia orange orchard. Soil Sci. 117:369-377.

Boman, B.J. 2005. Salinity effects on Florida grapefruit in the Indian River region. Hort Technology 15:89-95.

Brumós, J., J.M. Colmenero-Flores, A. Conesa, P. Izquierdo, G. Sánchez, D.J. Iglesias, M.F. López-Climent, A. Gómez-Cadenas, and M. Talón. 2009. Membrane transporters and carbon metabolism implicated in chloride homeostasis differentiate salt stress responses in tolerant and sensitive citrus rootstocks. Funct. Integr. Genomics 9:293309.

Castle, W.S. 2010. A career perspective on citrus rootstock, their development and commercialization. HortScience 45:11-15.

Cerdá, A., M. Nieves, and M. Guillén. 1990. Salt tolerance of lemon trees as affected by rootstocks. Irrig. Sci. 11:245-249.

Colmenero-Flores, J.M., G. Martinez, G. Gamba, N. Vazquez, D.J. Iglesias, J. Brumos, and M. Talón. 2007. Identification and functional characterization of cation-chloride cotransporters in plants. Plant J. 50:278-292.

Cooper, W.C. 1961. Toxicity and accumulation of salts in citrus trees on various rootstocks in Texas. Proc. Florida State Hort. Soc. 74:95104. 
Cooper, W.C., E.O. Olson, N. Maxwell, and G. Otey. 1956. Review of studies on adaptability of citrus varieties as rootstocks for grapefruit in Texas. J. Río Grande Valley Hort. Soc. 10:6-19.

Cuartero, J.M., C. Bolarín, M.J. Asins, and V. Moreno. 2006. Increasing salt tolerance in the tomato. J. Expt. Bot. 57:1045-1058.

Dasberg, S., H. Bielorai, A. Haimowitz, and Y. Erner. 1991. The effect of saline irrigation water on Shamouti orange trees. Irrig. Sci. 12:205-211.

Estañ, M.T., I. Villalta, M.C. Bolarín, E.A. Carbonell, and M.J. Asins. 2009. Identification of fruit yield loci controlling the salt tolerance conferred by Solanum rootstocks. Theor. Appl. Genet. 118:305-312.

Flowers, T.J. 2004. Improving crop salt tolerance. J. Expt. Bot. 55:307-319.

Food and Agriculture Organization of the United Nations. 2008. FAO land and plant nutrition management service. 12 May 2014. < http:// www.fao.org/ag/agl/agll/spush/>.

García, M.R., M.J. Asins, J. Forner, and E.A. Carbonell. 1999. Genetic analysis of apomixis in Citrus and Poncirus by molecular markers. Theor. Appl. Genet. 99:511-518.

García, M.R., G.P. Bernet, J. Puchades, I. Gómez, E.A. Carbonell, and M.J. Asins. 2002. Reliable and easy screening technique for salt tolerance of citrus rootstocks under controlled environments. Austral. J. Agr. Res. 53:653-662.

García-Sánchez, F., M. Carvajal, A. Cerdá, and V. Martinez. 2003. Response of Star Ruby grapefruit on two rootstocks to $\mathrm{NaCl}$ salinity. J. Hort. Sci. Biotechnol. 78:859-865.

García-Sánchez, F., J.G. Pérez-Pérez, P. Botía, and V. Martínez. 2006. The response of young mandarin trees grown under saline conditions depends on the rootstock. Eur. J. Agron. 24:129-139.

Gilliam, J.W. 1971. Rapid measurement of chlorine in plants materials. Proc. Soil Sci. Amer. Soc. 35:512-513.

Grieve, A.M., L.D. Prior, and K.B. Bevington. 2007. Long-term effects of saline irrigation water on growth, yield, and fruit quality of Valencia orange trees. Austral. J. Agr. Res. 58:342-348.

Grieve, A.M. and R.R. Walker. 1983. Uptake and distribution of chloride, sodium, and potassium ions in salt-treated citrus plants. Austral. J. Agr. Res. 34:133-143.

HunterLab. 1996. Hunter Lab color scale, insight on color 89 (Aug. 1-15). HunterLab, Reston, VA.

InfoStat. 2004. InfoStat software 2004 version. FCA. Universidad Nacional de Córdoba, Cordoba, Argentina.

Koyama, M.L., A. Levesley, R.M.D. Koebner, T.J. Flowers, and A.R. Yeo. 2001. Quantitative trait loci for component physiological traits determining salt tolerance in rice. Plant Physiol. 125:406-422.

Lauchli, A. and S.R. Grattan. 2007. Plant growth and development under salinity stress, p. 1-32. In: Jenks, M.A., P.A. Hasegawa, and S.M. Jain (eds.). Advances in molecular-breeding toward drought and salt tolerant crops. Springer, Houten, The Netherlands.

Leidi, E.O., V. Barragán, L. Rubio, A. El-Hamdaoui, M.T. Ruiz, B. Cubero, J.A. Fernández, R.A. Bressan, P.M. Hasegawa, F.J. Quintero, and J.M. Pardo. 2010. The AtNHX1 exchanger mediates potassium compartmentation in vacuoles of transgenic tomato. Plant $\mathrm{J}$. 61:495-506.

Levy, Y. and J. Syvertsen. 2004. Irrigation water quality and salinity effects in citrus trees. Hort. Rev. 30:37-82.

Maas, E.V. 1993. Salinity and citriculture. Tree Physiol. 12:195-216. Moya, J.L., A. Cadenas, E. Primo-Millo, and M. Talon. 2003. Chloride absorption in salt-sensitive Carrizo citrange and salt-tolerant Cleopatra mandarin citrus rootstocks is linked to water use. J. Expt. Bot. 54:825-833.

Munns, R. and M. Tester. 2008. Mechanisms of salinity tolerance. Annu. Rev. Plant Biol. 59:651-681.

Navarro, J.M., A. Gomez-Gomez, J.G. Perez-Perez, and P. Botia. 2010. Effect of saline conditions on the maturation process of Clementine fruits on two different rootstocks. Span. J. Agr. Res. 8:S21-S29.
Pardo, J.M. and F. Rubio. 2011. $\mathrm{Na}^{+}$and $\mathrm{K}^{+}$transporters in plant signalling, p. 79-90. In: Geisler, M. and K. Venema (eds.). Transporters and pumps in plant signaling. Springer-Verlag, Düsseldorf, Germany.

Porat, R., D. Pavoncello, G. Ben-Hayyim, and S. Lurie. 2002. A heat treatment induced the expression of a Na$/ \mathrm{H}^{+}$antiport gene (cNHX1) in citrus fruit. Plant Sci. 162:957-963.

Prior, L.D., A.M. Grieve, K.B. Bevington, and P.G. Slavich. 2007. Long-term effects of saline irrigation water on Valencia orange trees: Relationships between growth and yield, and salt levels in soil and leaves. Austral. J. Agr. Res. 58:349-358.

Raga, V., G.P. Bernet, E.A. Carbonell, and M.J. Asins. 2012. Segregation and linkage analyses in two complex populations derived from the salt tolerant citrus rootstock Cleopatra mandarin. Inheritance of seed reproductive traits. Tree Genet. Genomes 8:1061-1071.

Ream, C.L. and J.R. Furr. 1976. Salt tolerance of some Citrus species, relatives, and hybrids tested as rootstocks. J. Amer. Soc. Hort. Sci. 101:265-267.

Ruiz, C., M.P. Bretó, and M.J. Asins. 2000. An efficient methodology to identify sexual seedlings in citrus breeding programs using SSR markers. Euphytica 112:89-94.

Ruiz, D., V. Martinez, and A. Cerdá. 1999. Demarcating specific ion $(\mathrm{NaCl}, \mathrm{Cl}, \mathrm{Na}$ ) and osmotic effects in the response of two rootstock to salinity. Sci. Hort. 80:213-224.

Shannon, M.C. and C.M. Grieve. 1999. Tolerance of vegetable crops to salinity. Sci. Hort. 78:5-38.

Soler, J. 1999. Reconocimiento de variedades de cítricos en campo. Consellería de Agricultura, Pesca y Alimentación, Generalitat Valenciana. Serie de Divulgación Técnica No. 43.

Storey, R. and R.R. Walker. 1999. Citrus and salinity. Sci. Hort. 78:3981.

Sykes, S.R. 1985. A glasshouse screening procedure for identifying citrus hybrids which restrict chloride accumulation in shoot tissues. Austral. J. Agr. Res. 36:779-789.

Sykes, S.R. 1992. The inheritance of salt exclusion in woody perennial fruit species. Plant Soil 146:123-129.

Sykes, S.R. 2011. Chloride and sodium excluding capacities of citrus rootstock germplasm introduced to Australia from the People's Republic of China. Sci. Hort. 128:443-449.

Syvertsen, J. and Y. Levy. 2005. Salinity interactions with other abiotic and biotic stresses in citrus. HortTechnology 15:100-103.

Syvertsen, J.P., J.C. Melgar, and F. Garcia-Sánchez. 2010. Salinity tolerance and leaf water use efficiency in citrus. J. Amer. Soc. Hort. Sci. 135:33-39.

Tozlu, I., C.L. Guy, and G.A. Moore. 1999. QTL analysis of $\mathrm{Na}^{+}$and $\mathrm{Cl}^{-}$accumulation related traits in an intergeneric $\mathrm{BC} 1$ progeny of Citrus and Poncirus under saline and non-saline environments. Genome 42:692-705.

van Ooijen, J.W. 2009. MapQTL 6 software for the mapping of quantitative trait loci in experimental populations of diploid species. Kyazma, Wageningen, The Netherlands.

Venema, K., A. Belver, M.C. Marín Manzano, M.P. Rodriguez Rosales, and J.P. Donaire. 2003. A novel intracellular $\mathrm{K}^{+} / \mathrm{H}^{+}$ antiporter related to $\mathrm{Na}^{+} / \mathrm{H}^{+}$antiporters is important for $\mathrm{K}^{+}$ion homeostasis in plants. J. Biol. Chem. 278:22453-22459.

Villalta, I., G.P. Bernet, E.A. Carbonell, and M.J. Asins. 2007. Comparative QTL analysis of salinity tolerance in terms of fruit yield using two Solanum populations of $\mathrm{F}_{7}$ lines. Theor. Appl. Genet. 114:1001-1017.

Villalta, I., A. Reina-Sánchez, M.C. Bolarín, J. Cuartero, A. Belver, K. Venema, E.A. Carbonell, and M.J. Asins. 2008. Genetic analysis of $\mathrm{Na}^{+}$and $\mathrm{K}^{+}$concentrations in leaf and stem as physiological components of salt tolerance in tomato. Theor. Appl. Genet. 116:869-880.

Walker, R., E. Torokfalvy, and W. Downton. 1982. Photosynthetic responses of the citrus varieties Rangpur lime and Etrog citron to salt treatment. Austral. J. Plant Physiol. 9:783-790. 
Walker, R.R. 1986. Sodium exclusion and potassium-sodium selectivity in salt-treated trifoliate orange (Poncirus trifoliata) and Cleopatra mandarin (Citrus reticulata) plants. Austral. J. Plant Physiol. 13:293-303.

White, P.J. and M.R. Broadley. 2001. Chloride in soils and its uptake and movement within the plant: A review. Ann. Bot. (Lond.) 88:967988.

Witcombe, J.R., P.A. Hollington, C.J. Howarth, S. Reader, and K.A. Steele. 2008. Breeding for abiotic stresses for sustainable agriculture. Philosophical Trans. Royal Soc. B 363:703-716.
Yakushiji, H., H. Nonami, T. Fukuyuma, S. Ono, N. Takagi, and Y. Hoshimoto. 1996. Sugar accumulation enhanced by osmoregulation in Satsuma mandarin fruit. J. Amer. Soc. Hort. Sci. 121:466-472.

Yamaguchi, T., S. Hamamoto, and N. Uozumi. 2013. Sodium transport system in plant cell. Front. Plant Sci. 4:410.

Yukushiji, H., K. Morinaga, and H. Nonami. 1998. Sugar accumulation and partitioning in Satsuma mandarin tree tissues and fruit in response to drought stress. J. Amer. Soc. Hort. Sci. 123:719726. 


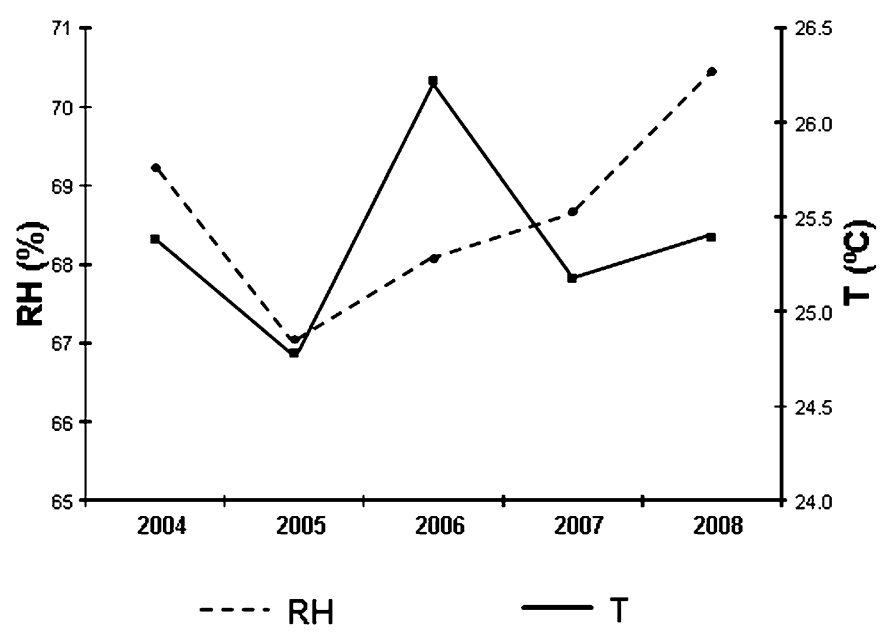

Supplemental Fig. 1. Undernet mean relative humidity (RH) and averaged temperature (T) recorded at Instituto Valenciano de Investigaciones Agrarias (Valencia, Spain) meteorological station for the 5 yielding years during the salt treatment period. 